\title{
Recombinant BCG expressing the leishmania surface antigen Gp63 induces protective immunity against Leishmania major infection in BALB/c mice
}

\author{
S. Abdelhak, ${ }^{1}$ H. Louzir, ${ }^{2}$ J. Timm, ${ }^{1}$ L. Blel, $^{2}$ Z. Benlasfar, ${ }^{2}$ M. Lagranderie, ${ }^{3}$ \\ M. Gheorghiu, ${ }^{3}$ K. Dellagi ${ }^{2}$ and B. Gicquel ${ }^{1}$
}

Author for correspondence: S. Abdelhak. Tel: +33 1 45688840. Fax: +33 145688843.

e-mail: abdelhak@pasteur.fr

1,3 Unité de Génétique
Mycobactérienne (CNRS
URA 1300) ${ }^{1}$ and
Laboratoire du BCG ${ }^{3}$,
Institut Pasteur de Paris,
25 rue du Dr Roux, 75724
Paris Cedex 15, France
2 Laboratoire
d'Immunologie, Institut
Pasteur de Tunis, Tunisia

\begin{abstract}
We have cloned and expressed the gp63 gene of Leishmania major in BCG to develop a recombinant vaccine against zoonotic cutaneous leishmaniasis. Two different expression systems were investigated. The first system consists of pAN, a Mycobacterium paratuberculosis promoter, which drives expression of ORF2, an open reading frame in IS900. This system allows the production of heterologous polypeptides as hybrids with the ORF2 gene product. The second expression system relies on the production of antigenic fragments as fusion proteins with the $\mathrm{N}$-terminal region of Mycobacterium fortuitum $\beta$-lactamase. Both constructs resulted in the production of Gp63 in BCG. The ability of the two recombinant BCG strains to induce protective immunity against a challenge with $L$. major amastigotes was evaluated after vaccination of susceptible (BALB/C), and resistant (C57BL/6) mice. Recombinant BCG producing Gp63 as a hybrid protein with the $\mathbf{N}$-terminal region of the $\beta$-lactamase elicited significant protection against a challenge with $L$. major in BALB/c-immunized mice.
\end{abstract}

Keywords: Leishmania, Gp63, recombinant BCG, protective immunity

\section{INTRODUCTION}

The bacillus of Calmette and Guérin (BCG) is a particularly attractive vector for the development of recombinant vaccines (Bloom, 1989). It has already been used to immunize more than 2.5 billion people with a very low incidence of serious complications and it can be given at or any time after birth. BCG itself is a potent adjuvant: a single inoculum can elicit long-term immunity (Bloom, 1989).

A growing array of integrative and extrachromosomal expression vectors has been developed over recent years, enabling cloning and expression of foreign genes in BCG (Snapper et al., 1988; Ranes et al., 1990; Matsuo et al., 1990). Various expression cassettes have been described for efficient expression of HIV1 Gag and Env structural proteins (Aldovini \& Young, 1991; Stover et al., 1991), and the regulatory protein Nef (Winter et al., 1991), tetanus toxin and $\beta$-galactosidase (Stover et al., 1991;

Abbreviations: $\mathrm{BCG}$, bacillus of Calmette and Guérin; $\mathrm{CL}$, cutaneous leishmaniasis; i.v., intravenous(ly); s.c., subcutaneous(ly).
Murray et al., 1992) in BCG. Several recombinant BCG strains induce specific cellular and humoral immune responses in mice (Aldovini \& Young, 1991; Stover et al., 1991; Winter et al., 1991; Murray et al., 1992). Protective immunity against Lyme disease elicited by recombinant BCG against challenge with Borrelia burgdorferi has also been reported (Stover et al., 1993).

Leishmania are obligate intracellular protozoan parasites of macrophages. They cause leishmaniasis, a major infectious disease of considerable public health and economic importance (WHO, 1984). Leishmaniasis includes a broad spectrum of diseases, ranging from simple cutaneous to visceral leishmaniasis (Chang \& Bray, 1985), according to the parasite species and to the host's susceptibility.

With the aim of developing a recombinant vaccine against cutaneous leishmaniasis, we cloned and expressed the gp63 gene of Leishmania major (the causative agent) in BCG. Vaccination against cutaneous leishmaniasis is feasible in principle, since individuals who develop the disease acquire long-term immunity against reinfection. Deliberate infection with the virulent cutaneous leish- 
manial parasite has been the basis for vaccination programmes in Israel and in countries of the former USSR (Greenblatt, 1980). However, complications associated with such immunization indicated the need for a killed, attenuated or subunit vaccine for CL. Killed Leishmania organisms and soluble extracts of promastigotes have been successfully used for immunizing animals (Howard et al., 1984; Liew et al., 1984; Mitchell \& Handman, 1983; Scott et al., 1987) and humans (Adler \& Gunders, 1964; Lainson \& Shaw, 1977; Mayrink et al., 1985). In addition, administration to mice of several purified leishmanial antigens including lipophosphoglycan (Handman \& Mitchell, 1985), surface glycoproteins, Gp63 (Russell \& Alexander, 1988) and Gp46/M2 (Champsi \& McMahonPratt, 1988), confers significant protection against leishmaniasis. Effective immunization with these subunit vaccines requires continuous boosters in the presence of an adjuvant. However the same antigen can induce protection against or exacerbation of the disease depending on the route of vaccination (Liew et al., 1985a, b).

Live recombinant vaccines, expressing leishmanial antigens, have been recently investigated as delivery systems for inducing appropriate and long-term immunological responses leading to protection against challenge with Leishmania parasites. Different inbred mice strains can be classified as resistant or susceptible to leishmaniasis (reviewed by Blackwell, 1989; Blackwell et al., 1991). Resistant CBA mice orally immunized with the Aro ${ }^{-}$ vaccine strain of Salmonella typhimurium transformed with the full-length $L$. major g $p 63$ gene preferentially developed a Th1 response that led to protective immunity against infection with Leishmania mexicana (Yang et al., 1990). Susceptible BALB/c mice immunized with recombinant vaccinia virus expressing GP46/M2 were significantly protected against a challenge with Leishmania amazonensis (McMahon-Pratt et al., 1993). A recent report (Connell et al., 1993) has shown that BCG expressing Gp63 as a fusion protein with the BCG bsp60 gene product engendered a protective response against a challenge with $L$. mexicana promastigotes and amastigotes after immunization of CBA and BALB/c mice. This recombinant $\mathrm{BCG}$ strain protected resistant $\mathrm{CBA}$ mice but not susceptible $\mathrm{BALB} / \mathrm{c}$ mice against a challenge with $L$. major, although lesion development within this group was less severe than in untreated and BCG control groups (Connell et al., 1993).

We analysed the expression of the gp63 gene of L. major under the control of two different mycobacterial expression systems. The ability of the recombinant BCG$g p 63$ vaccines to induce protective immunity against a challenge with $L$. major was evaluated after vaccination of susceptible (BALB/c) or resistant (C57BL/6) mouse strains. One of the expression systems led to significant protection against a challenge with $L$. major in immunized $\mathrm{BALB} / \mathrm{c}$ mice.

\section{METHODS}

Bacterial strains, plasmids, parasites and culture conditions. The bacterial strains, plasmids and parasites used in this study are listed in Table 1. Escherichia coli strains were grown in Lbroth supplemented with appropriate antibiotics and were transformed as described by Sambrook et al. (1989). Mycobacterial strains were transformed by electroporation as described previously (Ranes et al., 1990). Recombinant BCG clones were first cultivated on Lowenstein-Jensen medium containing $10 \mu \mathrm{g}$ kanamycin $\mathrm{ml}^{-1}$, then transferred onto Sauton medium for classical vaccine preparation or grown as a dispersed culture (Gheorghiu et al., 1988). L. major strain TN435 was cultured in RPMI 1640 supplemented with $10 \%$ inactivated foetal calf serum (Hyclone Laboratories) (Jaffe et al., 1984). L. major amastigotes were obtained by passaging strain PSA.18.SBZ, isolated from the rodent Psammomys obesus from the region of Sidi Bou Zid (Tunisia), and passaged in vivo five times in BALB/c mice.

Construction of expression vectors. The Gp63 protein precursor of L. major is encoded by an ORF of $1.8 \mathrm{~kb}$, of which $1.5 \mathrm{~kb}$ encodes the mature form of Gp63 (Button \& McMaster, 1988). The DNA fragment coding for the mature protein was synthesized in vitro by PCR amplification from genomic DNA of L. major strain TN435 (kindly provided by R. Ben Ismaill, Institut Pasteur de Tunis: Ben Ismail et al., 1986). Translational initiation and termination codons, and restriction sites for the subsequent cloning, were added. The sequences of the $5^{\prime}$ and $3^{\prime}$ primers are 5'-GCGGGATCCTTATGCATGTGCGCGACGTGAACTGGGGC-3' (the Bam $\mathrm{HI}$ and $N s i \mathrm{I}$ sites are underlined) and 5'-CCGAATTCAAGCTTCTACGCCGTGTTGCCGCCGTCCT'T-3' (the HindIII site is underlined); an ATG start codon and a stop codon were included (in bold).

The $g p 63$ gene was then cloned in plasmids pAM311 and pIPJ42*. Plasmid pAM311 is a pUC18 derivative containing a $1.6 \mathrm{~kb}$ fragment from Mycobacterium paratuberculosis harbouring the $\mathrm{p} A N$ promoter and ORF2 (Murray et al., 1992). Plasmid pIPJ42* is a pUC18 vector harbouring at the Bam HI site the $\beta$ lactamase gene bla $F$ with the regulatory region of bla $F^{*}$, which overproduces $\beta$-lactamase (Timm et al., 1994a). pIPJ46 is a pSL1180 derivative harbouring the origin of replication, oriM, of the M. fortuitum plasmid pAL5000 (Ranes et al., 1990) and the kanamycin-resistance gene, $a p h$, from $\operatorname{Tn} 903$ (Kanamycin Resistance Gen-Block, Pharmacia). pIPJ46 was used as a source of the oriMaph cassette for both the E. coli/mycobacteria shuttle plasmids, which were named pIPS11 (pAM311 derivative) and pIPS42 (pIPJ42* derivative). These plasmids were introduced into $M$. smegmatis and BCG by electroporation as previously described (Winter et al., 1991).

SDSPAGE and Western blotting. Total protein extracts of $M$. bovis BCG strains were prepared as described previously (Winter et al., 1991). Proteins were separated on $0 \cdot 1 \%$ SDS-10\% (w/v) polyacrylamide gels according to Laemmli (1970). After electroblotting, the membranes were incubated with a monoclonal antibody directed against Gp63 produced in E. coli (kindly provided by W. R. MacMaster, University of British Columbia, Vancouver, Canada: Button et al., 1991). The membranes were washed and incubated with horseradish-peroxidase-conjugated sheep anti-mouse second antibody and developed with the ECL chemiluminescent substrate according to the manufacturer's instructions (Amersham).

Evaluation of protection against infection with $\boldsymbol{L}$. major. Four groups of $8-10 \mathrm{BALB} / \mathrm{c}$ or $\mathrm{C} 57 \mathrm{BL} / 6$ mice were immunized twice at a one-month interval with $10^{6}$ c.f.u. given intravenously (i.v.) or $10^{7}$ c.f.u. given subcutaneously (s.c.) of 
Table 1. Bacterial strains and plasmids

\begin{tabular}{|c|c|c|}
\hline & Relevant characteristics & Source/reference \\
\hline \multicolumn{3}{|l|}{ Bacteria } \\
\hline M. smegmatis mc2 155 & $\begin{array}{l}\text { High-transformation mutant of } \\
\text { M. smegmatis ATCC } 607\end{array}$ & Snapper et al. (1988) \\
\hline M. bovis $\mathrm{BCG}$ & Vaccine strain $1173 \mathrm{P} 2$ & $\begin{array}{l}\text { BCG laboratory collection, } \\
\text { Institut Pasteur de Paris }\end{array}$ \\
\hline E. coli MC1061 & $\begin{array}{l}\text { bsdR2 bsdM }{ }^{+} \text {bsdS } S^{+} \text {araD139 } \\
\Delta(\text { ara }-l e u)_{7697} \Delta(\text { lac }) x_{74} \text { galE15 galK16 } \\
\quad r p s L\left(S t r^{r}\right) \operatorname{mcr} A \text { mcrB1 }\end{array}$ & Casadaban \& Cohen (1980) \\
\hline \multicolumn{3}{|l|}{ Plasmids } \\
\hline pAM311 & $\begin{array}{l}\text { pUC18 carrying the } \mathrm{p} A N \text { promoter and } \\
\text { a fragment coding for the } \mathrm{N} \text {-terminal } \\
\text { region of ORF } 2 \text { from IS } 900\end{array}$ & Murray et al. (1992) \\
\hline pIPJ46 & $\begin{array}{l}\text { pSL1180 derivative carrying the oriMaph } \\
\text { cassette }\end{array}$ & Timm et al. (1994b) \\
\hline pIPJ42* & $\begin{array}{l}\text { pUC18 containing blaF under control of } \\
\text { pblaF* }\end{array}$ & Timm et al. (1994b) \\
\hline \multicolumn{3}{|l|}{ Parasites } \\
\hline L. major TN435 & MON25 MHOM/TN/88/TN435 & Institut Pasteur de Tunis \\
\hline L. major PSA.18.SBZ & MON25 MPSA/TN/92/PSA.18.SBZ & Institut Pasteur de Tunis \\
\hline
\end{tabular}

the BCG vaccine strain 1173P2, recombinant BCG strains IPS42 and IPS11, or no vaccine (naive mice). One month after the booster injection, mice were challenged in one hind footpad with $2 \times 10^{6}$ amastigotes isolated from the footpad of an infected mouse, as follows. The foot was ground with a cell dissociation sieve-tissue grinder kit (Sigma). Amastigotes were counted and resuspended in PBS at a concentration of $4 \times 10^{7} \mathrm{ml}^{-1}$.

The footpad swelling was estimated by measurement of the foot circumference and subtracting the foot circumference on the day of challenge. At the end of the experiment $(120 \mathrm{~d}$ after challenge) mice were killed and parasites were recovered from the footpad and counted as described above.

In vitro lymphoproliferative responses to leishmanial antigen. At day 120 after infection with L. major, mice were killed, and popliteal lymph nodes draining the cutaneous lesion removed. Mononuclear cells were plated at $4 \times 10^{5}$ cells per well in 96-well tissue culture plates in $200 \mu \mathrm{l} \mathrm{RPMI} 1640$ (Flow Laboratories) supplemented with $5 \%(\mathrm{v} / \mathrm{v})$ heat-inactivated foetal calf serum (Hyclone Laboratories), penicillin $\left(100 \mathrm{U} \mathrm{ml}^{-1}\right)$, streptomycin $\left(50 \mu \mathrm{g} \mathrm{ml}^{-1}\right)$, and $50 \mu \mathrm{M} 2$-mercaptoethanol. Promastigotes from $L$. major strain TN435 were sonicated and centrifuged at $47000 \mathrm{~g}$ and the supernatant containing soluble leishmanial antigens (Sacks $e t$ al., 1987), was used as stimulating antigen at the final concentration of $20 \mu \mathrm{g} \mathrm{ml}^{-1}$. Cultures were incubated at $37^{\circ} \mathrm{C}$ with $5 \% \mathrm{CO}_{2}$, and on day 5 , cells were pulsed with $0.5 \mu \mathrm{Ci}(18.5 \mathrm{kBq})$ $\left[{ }^{3} \mathrm{H}\right]$ thymidine (Amersham) for $18 \mathrm{~h}$. Cells were then harvested and counted with a $\beta$ scintillation counter. The results are expressed as mean c.p.m. of triplicate cultures and as $\Delta$ c.p.m. [(mean counts of antigen-stimulated mononuclear cells) - (mean counts of unstimulated mononuclear cells)].

Statistical tests. Data were analysed for statistical significance by using the Mann-Whitney $\mathrm{U}$ test, which is the nonparametric version of the two-group unpaired $t$-test. Data were considered significant at $P<0 \cdot 05$.

\section{RESULTS}

\section{Cloning and expression of gp63 in BCG}

Two different systems were used to drive the expression of $g p 63$ in BCG. The first system allows the production of

$\begin{array}{llll}1 & 2 & 3 & 4\end{array}$

$\mathrm{kDa}$

$97-$

$68-$

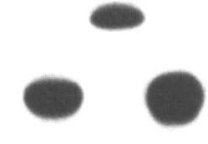

$43-$

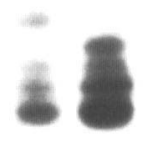

$29-$

Fig. 1. Western blot analysis of recombinant BCG clones with an anti-Gp63 monoclonal antibody. Lanes: 1, total protein extract from BCG 1173P2; 2, total protein extract from BCG clone harbouring pIPS42; 3 , total protein extract from BCG clone harbouring pIPS11; 4, L. major promastigote membrane extract. 


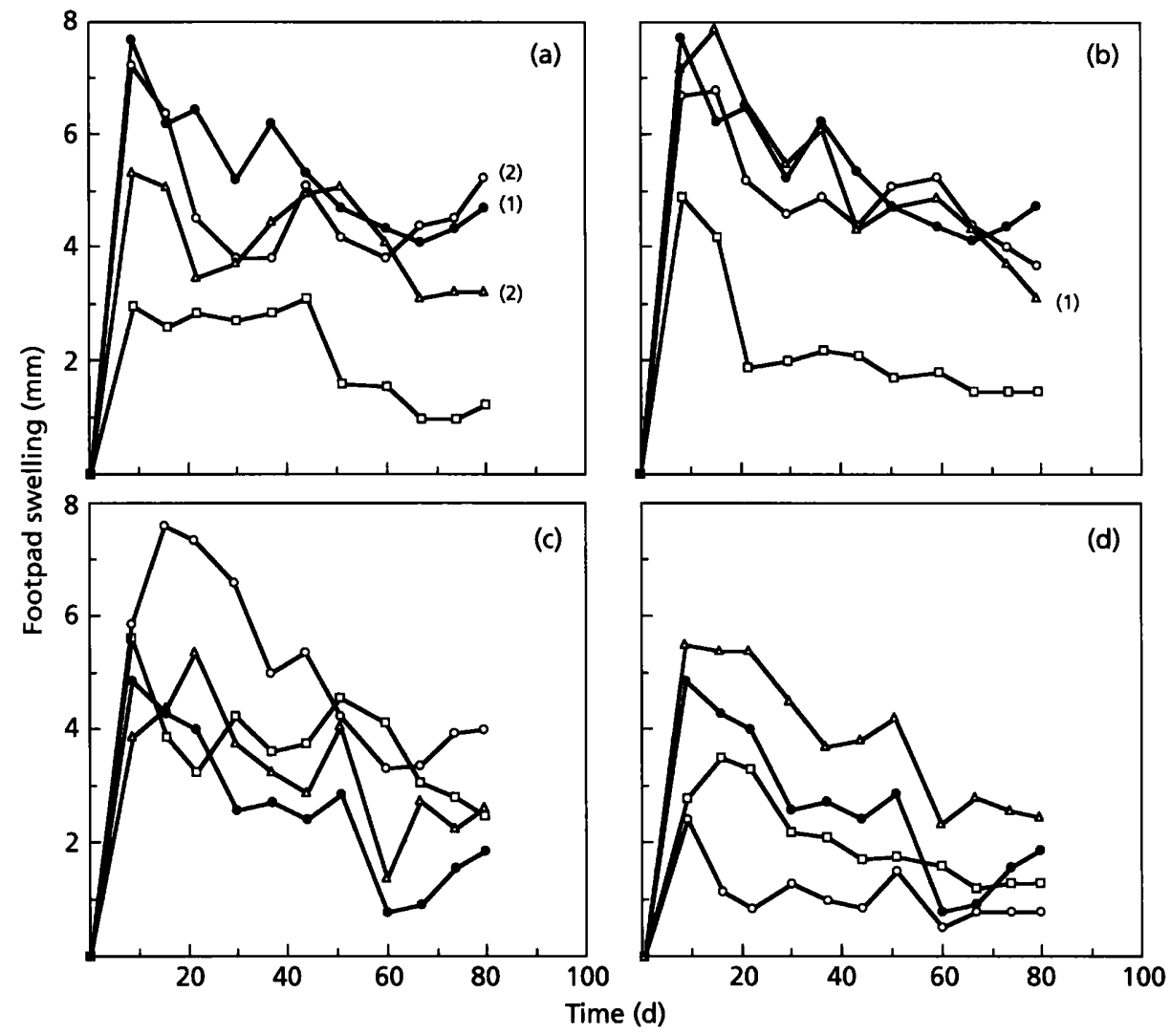

Fig. 2. Evaluation of protection against $L$. major infection in $B A L B / C(a, b)$ and $C 57 B L / 6$ (c, d) mice immunized subcutaneously $(a, c)$ or intravenously $(b, d)$ with classical $(1173 \mathrm{P} 2)$ or with recombinant BCG. Mean footpad swelling for each mouse group is indicated. The number of mice that lost their footpad or died before the end of the experiment is indicated in parentheses at the end of the respective plot. 0 , Naive; 0,1173 P2; $\square$, IPS42; $\triangle$, IPS11.

heterologous proteins in mycobacteria as fusions with the $\mathrm{N}$-terminus of the protein encoded by ORF2, an open reading frame of 382 codons which belongs to the insertion sequence IS 900 isolated from $M$. paratuberculosis. Expression of the fusion is driven by $\mathrm{p} A N$, a promoter located upstream of ORF2 (Murray et al., 1992). Previous studies have shown that analogous fusions of the lac $Z$ gene to the ORF2 sequence result in the production of fusion proteins with $\beta$-galactosidase activity in BCG (Murray et al., 1992). This recombinant BCG elicited T cell proliferative responses and anti- $\beta$-galactosidase antibody production in immunized mice.

The second expression system was recently developed for the production and export of heterologous proteins in mycobacteria (Timm et al., 1994a). This system relies on the production of antigenic fragments as fusions with the $\mathrm{N}$-terminal region of $\beta$-lactamase ( $\mathrm{BlaF})$. Expression is driven by a mutant of the $\beta$-lactamase gene promoter $\left(\mathrm{p} b l a F^{*}\right)$ isolated from an $M$. fortuitum strain overproducing $\beta$-lactamase.

The gp63 gene was synthesized in vitro by PCR amplification from genomic DNA of L. major strain TN435 and then cloned into plasmids harbouring the expression cassettes described above. The resulting E. coli/ myco- bacteria shuttle plasmids were named respectively pIPS11 and pIPS42. These plasmids were introduced into $M$. smegmatis and BCG by electroporation as previously described (Winter et al., 1991).

The production of the fused Gp63 proteins in BCG was assessed by Western blot analysis of total protein extracts using an anti-Gp63 monoclonal antibody (Button et al., 1991) (Fig. 1). The antibody recognized two major products in recombinant BCG strains: $73 \mathrm{kDa}$ and $63 \mathrm{kDa}$ polypeptides, corresponding to the fusion products between Gp63 and, respectively, the $\mathrm{N}$-terminal part of the polypeptide encoded by ORF2 and $\beta$-lactamase. The amount of the $\beta$-lactamase-Gp63 hybrid was consistently higher than that of the hybrid of Gp63 with the polypeptide encoded by ORF2 (Fig. 1 and data not shown). This is in accordance with recent studies showing that lac $Z$ expression in BCG from pbla $F^{*}$ resulted in a $\beta$ galactosidase activity in transformed BCG which was 6 times higher than that from $\mathrm{p} A N$ (Timm et al., 1994b). The $\beta$-lactamase-Gp63 fusion protein was found only in the total extract of the recombinant BCG cells and not in the culture medium (data not shown). This is consistent with previous studies showing that the signal sequence is essential but not sufficient for protein export (Moreno et al., 1980). 


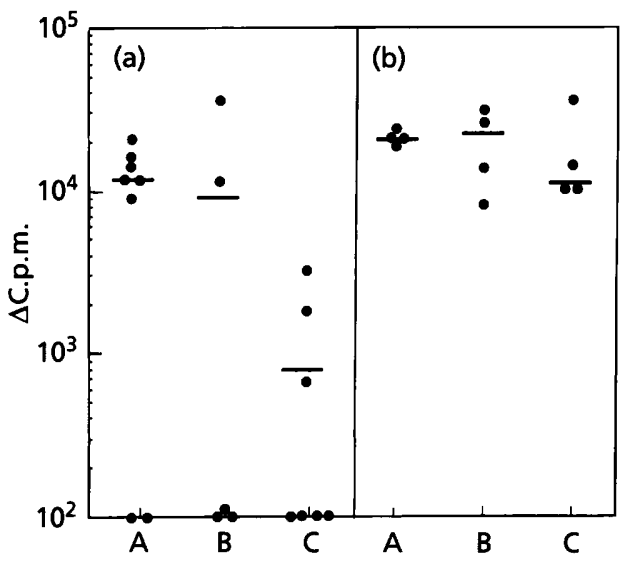

Fig. 3. Proliferative responses to soluble leishmanial antigens of popliteal lymph node cells of BALB/C (a) and C57BL/6 (b) mice. Each point represents the proliferative response in $\Delta$ c.p.m. for a single mouse receiving either recombinant (IPS42) (A) or nonrecombinant BCG (B) or of the control non-immunized group (C), challenged with $L$. major amastigotes. Bars represent arithmetic means of $\Delta$ c.p.m.

\section{Protection against $L$. major infection}

Four groups of $8-10 \mathrm{BALB} / \mathrm{c}$ or $\mathrm{C} 57 \mathrm{BL} / 6$ mice were immunized with two injections, at a one-month interval, of BCG or recombinant BCG by two different inoculation routes, i.v. or s.c. A control group of each mouse strain was not immunized. One month after the booster injection the mice were challenged with $2 \times 10^{6}$ L.major amastigotes. The development of cutaneous lesions was followed for 11 weeks after infection by measuring footpad swelling (Fig. 2).

The L. major strain TN435 caused a progressive disease in $\mathrm{BALB} / \mathrm{c}$ mice, but a self-resolving disease in C57BL/6 mice (Fig. 2). The ulcerative lesions induced in BALB/c mice by $L$. major strain TN435 were smaller than those caused by other strains described in the literature $(8-15 \mathrm{~mm})$. Despite the small size of the lesions, visceralization and severe evolution of the disease was observed, leading to the death of the animals.

$\mathrm{BALB} / \mathrm{c}$ mice inoculated with BCG producing the $\beta$ lactamase-Gp63 fusion protein (IPS42) had significantly $(P<0 \cdot 05)$ smaller lesions than controls.

IPS42 recombinant BCG administered by either route restricted lesion development. However, i.v. administration was associated with a more rapid regression of the lesion: its diameter regressed significantly $(P<0.05)$ from day 22 (fig. 2). Mouse groups immunized, by the s.c. or the i.v. route, with the non-recombinant BCG (1173P2) vaccine or with the recombinant BCG producing the ORF2-Gp63 fusion (IPS11) developed ulcerous lesions similar in size to those in the non-immunized control group.

C57BL/6 mice which did not receive BCG developed only a footpad swelling that regressed 6 weeks after challenge with $L$. major amastigotes, as has been reported for other mouse strains resistant to infection with $L$. major. The C57BL/6 mice, immunized s.c. or i.v. with BCG or with either recombinant BCG-gp63, developed footpad swelling similar to that in the control group. Lesion development in C57BL/6 mice, naturally resistant to $L$. major infection, was less pronounced only after i.v. immunization with BCG. This is consistent with previous reports describing a protective effect of BCG against $L$. major infection in mice (Fortier et al., 1987; Connell et al., 1993). In contrast to the control group, the footpad swelling of the immunized C57BL/6 mice did not regress completely 8 weeks after challenge. These lesions appeared different from those induced in susceptible $\mathrm{BALB} / \mathrm{c}$ mice: they were not ulcerated and were free of parasite on day 51 and at the end of the study. A histological examination of the foodpad swelling, performed in two mice of these groups, showed a faint interstitial oedema and a subcutaneous infiltrate of lymphocytes with few histiocytic cells. No Leishman bodies were detected.

\section{Evaluation of parasite load and cellular immune responses}

The best protection against $L$. major infection was thus obtained in BALB/c mice with recombinant BCG expressing Gp63 as a fusion protein with the $\mathrm{N}$-terminal region of $\beta$-lactamase (IPS42). Since the subcutaneous route of immunization appeared promising, we evaluated the cellular immune responses and the number of parasites at the site of challenge in mice injected s.c. during the protocol described above. Three groups of eight BALB/c and C57BL/6 mice received s.c. either IPS42 or nonrecombinant BCG or did not receive any vaccine. The mice were then challenged with L. major and killed $120 \mathrm{~d}$ later. The footpad of each mouse was ground in $2 \mathrm{ml}$ RPMI medium and $20 \mu \mathrm{l}$ tissue homogenate was analysed. The presence of one or more parasite per ten $40 \times$ magnification fields was scored as positive. In BALB/c mice immunized subcutaneously with IPS42, parasites were detected in two of eight mice. Five of eight mice immunized with BCG and all eight non-immunized mice were infected. In $\mathrm{C} 57 \mathrm{BL} / 6$ mice no parasites were detected in any group studied.

The proliferative responses of lymph node cells were also investigated in the different groups of mice listed above. The cells were stimulated in vitro with soluble leishmanial antigen (SLA), as described in Methods. Cells from six of eight mice immunized with IPS 42 proliferated vigorously in response to SLA (Fig. 3). In this group the unresponsive mice were those that had persistent cutaneous lesions. Two of six BALB/c mice immunized with BCG developed a lymphoproliferative response to SLA. The responsive mice had no parasites at the end of the study. All six BALB/c mice of the control group had low proliferative responses. In $\mathrm{C} 57 \mathrm{BL} / 6$ mice strong proliferation responses specific to SLA were found in all the groups tested. 


\section{DISCUSSION}

Upon clinical recovery from most forms of leishmaniasis, there is often effective and long-lasting resistance to recurrent disease. Several studies have shown that cellmediated immunity, rather than humoral antibodies, plays a role in the host defence and resistance to reinfection. For the cutaneous form of leishmaniasis, Th1 subsets of $\mathrm{CD}^{+}$cells producing $\gamma$-IFN are principally hostprotective, whereas the Th2 subsets secreting IL-3, IL-4 and IL- 5 are disease-promoting (reviewed by Titus $e t$ al., 1992).

Several protective antigens have been reported for murine experimental leishmaniasis. One of these antigens, Gp63, is of particular interest since it is expressed in both promastigote and amastigote stages. This antigen is present in all leishmanial species tested (Bordier, 1987) and is highly conserved (Webb et al., 1991). It has been postulated to play a role in the parasite's entry into the macrophage (Russell \& Wilhelm, 1986) and its subsequent survival in the phagolysosome through its non-specific proteinase activity (Chaudhuri et al., 1989). Gp63 has been demonstrated to be a protective antigen, but only in the presence of adjuvants or when presented by live recombinant bacteria (Russell \& Alexander, 1988; Yang et al., 1990; Connell et al., 1993).

A recent report has shown that BCG expressing Gp63 as protein fusion with the BCG $b s p 60$ gene product engendered a protective response against a challenge with L. mexicana promastigotes and amastigotes after immunization of CBA and BALB/c mice. This recombinant BCG strain protected resistant $\mathrm{CBA}$ mice but not susceptible $\mathrm{BALB} / \mathrm{c}$ mice against a challenge with $L$. major, although lesion development within this group was less than in untreated and BCG control groups (Connell et al., 1993).

In the present study, BALB/c mice were protected against $L$. major infection by a recombinant BCG expressing Gp63 as a fusion protein with $\beta$-lactamase. The same antigen expressed as a fusion protein with the IS900 ORF2 gene product failed to induce protective immunity. This might be due to the level of expression of $g p 63$, as differences in the expression level of heterologous protein between the two systems have been observed in vitro (a factor of 6 in pbla $F^{*}$ - versus $\mathrm{p} A N$-driven expression) (Timm et al., 1994b).

The ability of the gp63-recombinant BCG strain to reduce lesion development after $L$. major infection seems to be independent of the route of vaccination: only slight differences in the protective responses were observed between the i.v. or s.c. inoculation routes.

The reduction of lesion size in $\mathrm{BALB} / \mathrm{c}$ mice immunized with recombinant BCG IPS42 correlated with the absence of parasites at the site of challenge. C57BL/6 mice are resistant to leishmaniasis and develop protective proliferative responses during infection. There is no proliferative response during acute disease in $\mathrm{BALB} / \mathrm{c}$ mice. We found that a cellular response was induced in BALB/c mice immunized with gp63-recombinant BCG. Vacci- nation with recombinant $B C G$ expressing $g \not p 63$ converted the $\mathrm{BALB} / \mathrm{c}$ mice to a resistant phenotype. Studies are in progress to determine the pattern of cytokine secretion induced by vaccination.

Studies with animal model systems and humans indicate that there is cross-protection between Leishmania species that cause the cutaneous forms of the disease (Adler \& Gunders, 1964; Lainson \& Shaw, 1977). It would therefore be interesting to investigate the effect of recombinant BCG-gp63 in eliciting a protective immune response against other Leishmania species.

Previous studies of protective responses induced by recombinant $B C G$ strains used foreign antigens cloned on pAL5000-derived replicative plasmids. Preliminary studies have shown that recombinant BCG are stable in vivo: $1 / 3$ of recombinant $B C G$ harbouring the lac $Z$ gene, when injected into mice, showed $\beta$-galactosidase activity 3 months after inoculation (Murray et al., 1992). The use of live recombinant $B C G$ as a vaccine will require integrative vectors with strong expression systems allowing the construction of more stable recombinant strains. The present study shows that immunization with recombinant BCG harbouring $g p 63$ on a replicative plasmid can elicit appropriate immunological responses resulting in protection against infection. This study and others show that recombinant BCG expressing foreign antigens may provide the basis for an effective vaccine against various pathogens.

\section{ACKNOWLEDGEMENTS}

We thank R. McMaster for providing monoclonal antibodies to Gp63. We are grateful to C. Leclerc, G. Millon and T. Pugsley for fruitful discussions. We thank J. Rauzier and A. Sassi for technical assistance. S. Abdelhak was supported by the French Government (Ministère des Affaires Etrangères) and by the Fondation pour la Recherche Médicale. This work was supported by an EC grant (BIO-CT92-0520), by the UNDP/ World Bank/WHO Special Program for Research Training in Tropical Diseases (TDR) and by a Tunisian SERST research grant.

\section{REFERENCES}

Adler, S. \& Gunders, A. E. (1964). Immunity of Leishmania mexicana following spontaneous recovery from oriental sore. Trans $\mathrm{R}$ Soc Trop Med Hyg 58, 274-277.

Aldovini, A. \& Young, R. A. (1991). Humoral and cell-mediated immune responses to live recombinant BCG-HIV vaccines. Nature 351, 479-482.

Ben Ismall, R., Gradoni, L., Gramiccia, M., Behini, S. \& Ben Rachid, M. S. (1986). Epidemic cutaneous leishmaniasis in Tunisia. Biochemical characterization of parasites. Trans $\mathrm{R}$ Soc Trop Med Hyg 80, 669-670.

Blackwell, J. M. (1989). The macrophage resistance gene Lsh/ Ity/Bcg. Res Immunol 40, 767-826.

Blackwell, J. M., Roach, T. I. A., Atkinson, S. E., Ajioka, J. W., Barton, C. H. \& Shaw, M. A. (1991). Genetic regulation of macrophage priming activation: the Lsh gene story. Immunol Lett 30, 241-248.

Bloom, B. R. (1989). Vaccines for the third world. Nature 342, 115-120. 
Bordier, C. (1987). The promastigote surface protease of Leishmania. Parasitol Today 3, 151-153.

Button, L. L. \& McMaster, W. R. (1988). Molecular cloning of the major surface antigen of Leishmania. J Exp Med 167, 724-729.

Button, L. L., Reiner, N. E. \& McMaster, W. R. (1991). Modification of $g p 63$ genes from diverse species of Leishmania for expression of recombinant protein at high levels in Escherichia coli. Mol Biochem Parasitol 44, 213-224.

Casadaban, M. J. \& Cohen, S. N. (1980). Analysis of gene control signals by DNA fusion and cloning in Escherichia coli.J Mol Biol 138, 179-207.

Champsi, J. \& McMahon-Pratt, D. (1988). Membrane glycoprotein M-2 protects against Leishmania amazonensis infection. Infect Immun 56, 3272-3279.

Chang, K. P. \& Bray, R. S. (editors) (1985). Human Parasitic Diseases: the Leishmaniasis. Amsterdam: Elsevier.

Chaudhuri, G., Chaudhuri, M., Pan, A. \& Chang, K. P. (1989). Surface acid proteinase (gp63) of Leishmania mexicana: a metalloenzyme capable of protecting liposome-encapsulated proteins from the phagolysosomal degradation by macrophage. J Biol Chem 264, 7483-7489.

Connell, N. D., Medina-Acosta, E., McMaster, W. R., Bloom, B. R. \& Russell, D. G. (1993). Effective immunization against cutaneous leishmaniasis with recombinant bacille Calmette-Guérin expressing the Leishmania surface proteinase gp63. Proc Natl Acad Sci US A 90, 11473-11477.

Fortier, A. H., Mock, B. A., Meltzer, M. S. \& Nacy, C. A. (1987). Mycobacterium bovis $\mathrm{BCG}$-induced protection against cutaneous and systemic Leishmania major infections of mice. Infect Immun 55, 1707-1714.

Gheorghiu, M., Lagrange, P. \& Fillastre, C. (1988). The stability and immunogenicity of a dispersed grown freeze derived Pasteur BCG vaccine. J Biol Stand 16, 15-26.

Greenblatt, C. L. (1980). The present and the future of vaccination for cutaneous leishmaniasis. In New Developments with Human and Veterinary Vaccines, pp. 259-285. Edited by A. Mezhari, I. Hertman, M. A. Klinger \& A. Kohn. New York: Alan R. Liss.

Handman, E. \& Mitchell, G. F. (1985). Immunisation with Leishmania receptor for macrophages protects mice against cutaneous leishmaniasis. Proc Natl Acad Sci US A 82, 5910-5914.

Howard, J. G., Liew, F. Y., Hale, C. \& Nicklin, S. (1984). Prophylactic immunization against experimental leishmaniasis. II. Further characterization of the protective immunity against fatal Leishmania tropica infection induced by irradiated promastigotes. $J$ Immunol 134, 450-455.

Jaffe, C. L., Grimaldi, G. \& McMahon-Pratt, D. (1984). The cultivation and the cloning of Leishmania. In Genes and Antigens of Parasites. A Laboratory Manual, 2nd edn, The Proceedings of a Course Sponsored by UNDP/World Bank/WHO. Edited by C. Morel. WHO: Rio de Janeiro.

Laemmli, U. K. (1970). Cleavage of structural proteins during the assembly of the head of bacteriophage T4. Nature 227, 680-685.

Lainson, R. \& Shaw, J. J. (1977). Leishmaniasis in Brazil. XII. Observations on cross-immunity in monkeys and man infected with Leishmania mexicana mexicana, L. m. amazonensis, L. braziliensis braqiliensis, L. b. panamensis. Am J Trop Med Hyg 80, 29-35.

Liew, F. Y., Howard, J. G. \& Hale, C. (1984). Prophylactic immunization against experimental leishmaniasis. III. Protection against fatal Leishmania tropica infection induced by irradiated promastigotes involves $\mathrm{Lyt}-1^{+} 2^{-}$cells that do not mediate cutaneous DTH. J Immunol 134, 456-461.

Liew, F. Y., Hale, C. \& Howard, J. G. (1985a). Prophylactic immunization against experimental leishmaniasis. IV. Subcutaneous immunization prevents the induction of protective immunity against fatal Leishmania major infection. I Immunol 135, 2095-2101.

Liew, F. Y., Singleton, A., Cillari, E. \& Howard, J. G. (1985b). Prophylactic immunization against experimental leishmaniasis. V. Mechanism of the anti-protective blocking effect induced by subcutaneous immunization against Leishmania major infection. $J$ Immunol 135, 2102-2107.

McMahon-Pratt, D., Rodriguez, D., Rodriguez, J. R., Zhang, Y., Manson, K., Bergman, C., Rivas, L., Rodrigez, J. F., Lohman, K. L., Ruddle, N. H. \& Esteban, M. (1993). Recombinant vaccinia viruses expressing gp46/M-2 protect against Leishmania infection. Infect Immun 61, 3351-3359.

Matsuo, K., Yamaguchi, R., Yamasaki, A., Tasaka, K., Terasaka, M., Totsuka, K., Kobayashi, H., Yukitake, H. \& Yamada, T. (1990). Establishment of a foreign secretion system in mycobacteria. Infect Immun 58, 4049-4054.

Mayrink, W. P., Williams, P., Da costa, C. A., Magalhaes, P. A., Melo, M. N., Dias, M., Oliveira Lima, A., Michalick, M. S. M., Ferrura Carvalho, E., Barros, G. C., Sessa, P. A. \& De Alencar, J. T. A. (1985). An experimental vaccine against American dermal leishmaniasis: experience in the State of Espirito Santo, Brazil. Ann Trop Med Parasitol 79, 259-269.

Mitchell, G. F. \& Handman, E. (1983). Leishmania tropica major in mice: vaccination against cutaneous leishmaniasis in mice of high genetic susceptibility. Aust J Exp Biol Med Sci 61, 11-25.

Moreno, F., Fowler, A. V., Hall, M., Silhavi, T. G., Zabin, I. \& Schwartz, M. (1980). A signal peptide is not sufficient to lead $\beta$ galactosidase out of the cytoplasm. Nature 286, 356-359.

Murray, A., Winter, N., Lagranderie, M., Hill, D. F., Rauzier, J., Timm, J., Leclerc, C., Moriarty, K. M., Georghiu, M. \& Gicquel, B. (1992). Expression of Escherichia coli $\beta$-lactamase in Mycobacterium bovis BCG using an expression system isolated from Mycobacterium paratuberculosis which induced humoral and cellular immune responses. Mol Microbiol 6, 3331-3342.

Ranes, M. G., Rauzier J., Lagranderie M. M. G. \& Gicquel, B. (1990). Functional analysis of pAL5000, a plasmid from Mycobacterium fortuitum: Construction of a 'Mini' mycobacteriumEscherichia coli shuttle vector. J Bacteriol 172, 2793-2797.

Russell, D. G. \& Alexander, J. (1988). Effective immunization against cutaneous leishmaniasis with defined membrane-antigens reconstituted into liposomes. J Immunol 140, 1274-1279.

Russell, D. G. \& Wilhelm, H. (1986). The involvement of the major surface glycoprotein (gp63) of leishmania promastigotes in attachment to macrophages. J Immunol 136, 2613-2620.

Sacks, D. L., Suman, L. L., Shrivastava, S. N., Blackwell, J. \& Neva, F. A. (1987). An analysis of $T$ cell responsiveness in indian KalaAzar. J Immunol 138, 908-913.

Sambrook, J., Fritsch, E. F. \& Maniatis, T. (1989). Molecular Cloning: a Laboratory Manual. Cold Spring Harbor, NY: Cold Spring Harbor Laboratory.

Scott, P. E., Pearce, E., Natovitz, P. \& Sher, A. (1987). Vaccination against cutaneous leishmaniasis in a murine model. I. Induction of protective immunity with a soluble extract of promastigotes. $J$ Immunol 139, 221-227.

Snapper, S. B., Lugosi, L., Jekkel, A., Melton, R. E., Kieser, T., Bloom, B. R. \& Jacobs, W. R., Jr (1988). Lysogeny and transformation in mycobacteria: stable expression of foreign genes. Proc Natl Acad Sci US A 85, 6987-6991.

Stover, C. K., de la Cruz, V. F., Feurst, T. R., Burlein, J. E., Benson, L. A., Bennett, L. T., Bansal, G. P., Young, J. F., Lee, M. H., Hatfull, 
G. F., Snapper, S. B., Barletta, R. G., Jacobs, W. R. \& Bloom, B. R. (1991). New use of BCG for recombinant vaccines. Nature 351, 456-460.

Stover, C. K., Bansal, G. P., Hanson, M. S., Burlein, J. E., Palaszynski, S. R., Young, J. F., Koenig, S., Young, D. B., Sadziene, A. \& Barbour, A. G. (1993). Protective immunity elicited by recombinant Bacille Calmette-Guérin (BCG) expressing outer surface protein A (OspA) lipoprotein: a candidate Lyme disease vaccine. J Exp Med 178, 197-209.

Timm, J., Perilli, M. G., Duez, C., Trias, J., Orefici, G., Fattorini, L., Amicosante, G., Oratore, A., Joris, B., Frère, J. M., Pugsley, A. P. \& Gicquel, B. (1994a). Transcription and expression analysis, using lac $Z$ and $p b o A$ gene fusions, of Mycobacterium fortuitum $\beta$-lactamase genes cloned from a natural isolate and a high-level $\beta$-lactamase producer. Mol Microbiol 12, 491-504.

Timm, J., Lim, E. M. \& Gicquel, B. (1994b). Escherichia colimycobacteria shuttle vectors for operon and gene fusions to $\operatorname{lac} Z$ : the pJEM series. J. Bacteriol 176, 6749-6753.

Titus, R. G., Theodos, C. M., Kimsey, P. B., Shankar, A., Hall, L., McGurn, M. \& Povinelli, L. (1992). Role of T cells in immunity to the intracellular pathogen, Leishmania major. In Subcellular Biochemistry, pp. 99-129. Edited by J. L. Avila. \& J. R. Harris. New York: Plenum Press.

Webb, J. R., Button, L. L. \& McMaster, W. R. (1991). Heterogeneity of the genes encoding the major surface glycoprotein of Leishmania donovani. Mol Biochem Parasitol 48, 173-184.

WHO (1984). The leishmaniases. In Report of a WHO Expert Commitee. Technical Report Series no. 701.

Winter, N., Lagranderie, M., Rauzier, J., Timm, J., Leclerc, C., Guy, B., Kieny, M. P., Gheorghiu, M. \& Gicquel, B. (1991). Expression of heterologous genes in Mycobacterium bovis BCG: induction of a cellular response against HIV-1 Nef protein. Gene 109, 47-54.

Yang, D. M., Fairweather, N., Button, L. L., McMaster, W. R., Kahl, L. P. \& Liew, F. Y. (1990). Oral Salmonella typhimurium (AroA ${ }^{-}$) vaccine expressing a major leishmanial surface protein (gp63) preferentially induces $\mathrm{T}$ helper 1 cells and protective immunity against leishmaniasis. J Immunol 145, 2281-2285.

Received 10 November 1994; revised 24 February 1995; accepted 15 March 1995. 